\title{
KARAKTERISTIK BROWNIS KUKUS COKELAT BERBAHAN DASAR PATI GARUT DENGAN SUBTITUSI PARSIAL TEPUNG JEWAWUT
}

\author{
CHARACTERISTIC OF STEAMED-CHOCOLATE BROWNIES MADE FROM \\ ARROWROOT STARCH WITH PEARL MILLET FLOUR PARTIAL REPLACEMENT
}

\author{
Dimas Rahadian Aji Muhammad, Tabita Gita Sasti, Siswanti, R. Baskara Katri Anandito \\ Prodi Ilmu Teknologi Pangan, Fakultas Pertanian, Universitas Sebelas Maret, Jl. Ir. Sutami 36A Kentigan \\ Surakarta 57126 \\ email: dimasrahadian@staff.uns.ac.id
}

Diserahkan [1 Desember 2019]; Diterima [30 Januari 2020]; Dipublikasi [16 Februari 2020]

\begin{abstract}
The study aimed to investigate the sensory, physical and nutritional characteristics of steamed-chocolate brownies made from arrowroot starch with partial subtitution replacement of pearl millet (25\%, 50\%, 75\%). The result of sensory analysis showed that the steamed-chocolate brownies formulated with arrowroot starch and pearl millet flour at the ratio of 50:50 had the highest level of consumer acceptance, and thus selected as the sample product for the further analysis. The sample contained water (28,2\%), ash (1,8\%), protein (8,7\%) fat $(21,6 \%)$ carbohydrate $(77,1 \%)$ and dietary fiber $(3,1 \%)$. The product can contribute to $10 \%$ of the total daily requirement of dietary fiber particularly for children (i.e., 5-6 years old) and thus can be considered as a fiber source-food for those particular age range.
\end{abstract}

Keywords: steamed-brownies, arrowroot starch, pearl millet flour, subtitution

\section{ABSTRAK}

Tujuan penelitian ini adalah untuk mengetahui karakteristik sensoris, fisik, dan kimia serta angka kecukupan brownies kukus cokelat berbahan dasar pati garut dengan subtitusi tepung jewawut $(25 \%, 50 \%$, 75\%). Produk yang mempumyai nilai tertinggi dalam uji kesukaan konsumen adalah brownis kukus cokelat yang dibuat dari pati garut dan tepung jewawut dengan perbandingan 50:50. Oleh karena itu, sampel ini selanjutnya dipilih untuk digunakan dalam penelitian tahap selanjutnya. Sampel brownis kukus cokelat terpilih mempunyai kadar air 28,2\%, kadar abu 1,8\%, kadar protein 8,7\%, kadar lemak 21,6\%, kadar karbohidrat 77,1\%, dan serat pangan 3,1\%. Brownis kukus cokelat dengan subtitusi 50\% tepung jewawut memberikan kontribusi sebesar $10 \%$ dari total kebutuhan sehari serat pangan golongan anak usia 5-6 tahun, sehingga dapat dipertimbangkan sebagai makanan sumber serat bagi kelompok konsumen anak-anak pada rentang usia tersebut.

Kata Kunci : brownis kukus, pati garut, tepung jewawut, subtitusi

\section{PENDAHULUAN}

Pola makan masyarakat yang tidak teratur dengan asupan gizi yang kurang seimbang serta gaya hidup yang tidak sehat memicu timbulnya berbagai macam kasus penyakit degeneratif seperti obesitas, diabetes, jantung coroner dan hipertensi (de Ridder et al., 2017). Hal ini mendorong para peneliti di bidang pangan untuk mengembangkan dan mendesain produk pangan yang bermanfaat bagi kesehatan (Muhammad dan Dewettinck, 2017). Salah satu komponen bahan pangan yang dapat berperan bagi kesehatan adalah serat pangan, yaitu komponen bioaktif yang memiliki fungsi fisiologis seperti seperti anti kolesterol serta dapat bermanfaat untuk menjaga gula darah agar tetap normal (Dai et al., 2017;
Maphosa \& Jideani, 2016; Brownlee et al., 2017). Menurut Fuller et al. (2016) serat pangan dibagi menjadi dua golongan besar, yaitu serat pangan larut air (soluble dietary fiber) dan serat pangan tidak larut air (insoluble dietary fiber). Serat pangan larut air dapat larut di dalam air dan juga dalam saluran pencernaan sehingga dapat memberi rasa kenyang yang lebih lama, memperlambat penyerapan glukosa ke darah, dan menurunkan kolesterol. Serat pangan tidak larut air adalah serat yang tidak dapat larut di dalam air maupun di saluran pencernaan dengan fungsi utama mempercepat waktu laju aliran makanan dalam usus, meningkatkan volume feses, dan mencegah kanker kolon.

Produk bakery merupakan agen pembawa serat pangan yang potensial. 
Produk bakery fungsional yang memiliki nilai energi dan indeks glikemik rendah sebagai alternatif pangan fungsional telah mulai banyak dikembangkan (Arslan et al., 2019). Brownis cokelat merupakan salah satu produk turunan bakery jenis cake yang telah populer dan banyak beredar di pasaran Indonesia. Brownis kukus cokelat yang beredar di pasaran bahkan tidak hanya terbuat dari tepung terigu, tetapi juga jenis tepung lainnya, seperti pati garut (Maranta arundinaceae L.). Di Kota Solo, saat ini telah diproduksi secara komersial produk brownies kukus $100 \%$ pati garut sebagai salah satu pengembangan produk brownis oleh Toko Roti Ganeps, Surakarta. Dalam produk tersebut, diperkirakan mempunyai serat pangan yang masih rendah. Menurut Slamet et al. (2019), kadar serat pangan pati garut sebesar 2,16\%. Menurut regulasi BPOM (2011) suatu produk dapat diklaim sebagai sumber serat pangan jika komposisi serat pangan tidak kurang dari 3 gram/100 gram produk.

Jewawut (Pennisetum glaucum) merupakan salah satu serealia di Indonesia yang dikenal juga dengan nama pearl millet yang memiliki potensi sebagai serat pangan. Tepung jewawut mempunyai kadar protein $12,1 \%$, kadar lemak 1,68\%, karbohidrat $81,52 \%$ dan serat pangan 7,8\% (Dias-Martins et al, 2018). Subtitusi parsial tepung jewawut ke dalam formulasi brownis kukus cokelat diperkirakan dapat meningkatkan kadar serat produk brownis kukus. Namun, diduga subtitusi tepung jewawut akan berdampak pada karakteristik brownis kukus seperti pada warna, tekstur dan nilai gizi, serta diperkirakan berpengaruh terhadap kesukaan konsumen. Berdasarkan latar belakang tersebut, perlu dilakukan studi terhadap pengaruh subtitusi parsial tepung jewawut terhadap karakteristik brownis kukus cokelat berbahan dasar pati garut. Tujuan dari penelitian ini adalah mengetahui penerimaan panelis terhadap karakteristik sensoris brownis kukus cokelat pada parameter warna, aroma, rasa, tekstur dan overall yang diformulasikan dari tepung garut dan tepung jewawut. Selain itu, penelitian ini juga bertujuan untuk mengetahui pengaruh tepung jewawut terhadap karakteristik fisik (warna dan tekstur), kimia (kadar air, abu, lemak, protein, karbohidrat dan serat pangan), serta angka kecukupan gizi brownis kukus cokelat yang berbahan dasar tepung garut.

\section{METODE PENELITIAN}

\section{Bahan}

Bahan yang digunakan dalam penelitian ini adalah pati garut yang diperoleh dari Toko Roti Ganeps (Surakarta). Tepung jewawut diperoleh dari Gunung Kidul, Yogyakarta. Gula pasir Gulaku (PT. Sugar Group Companies, Lampung), telur ayam dari pasar tradisional di Kota Solo, pengemulsi SP Ryoto Ester (Mitsubishi Chemical Corporation, Jepang), coklat masak Colatta (PT. Gandum Mas Kencana, Tangerang), kakao bubuk Van Houten (PT. Ceres, Bandung), margarin Blue Band (KKR \& Co., Cikarang), serta vanili bubuk Koepoekoepoe (PT. Anggana Catur Prima, Jakarta) juga digunakan sebagai bahan untuk pembuatan brownis kukus cokelat.

\section{Alat}

Peralatan yang digunakan dalam pembuatan borwnis kukus cokelat antara lain mixer, loyang, kompor dan alat pengukus. Selain itu diperlukan peralatan analisa, seperti Chromameter Minolta CR-400 untuk analisa warna, Llyod Universal Testing Machine untuk analisa tekstur, tanur pengabuan unutk analisa kadar abu, sperangkat alat analisa kadar protein dengan metode kjedhal, serta sokhlet untuk analisa lemak dan serat pangan.

\section{Tahapan Penelitian}

Sampel brownis kukus cokelat yang dibuat dengan berbagai variasi formula (Tabel 1). Dalam pembuatan brownis kukus cokelat, adonan dibagi menjadi tiga, yaitu: (1) telur, gula, dan SP; (2) pati garut, tepung jewawut, coklat bubuk; (3) margarin dan coklat masak. 
Tabel 1 Variasi formulasi brownis kukus

\begin{tabular}{lcccc}
\hline \multirow{2}{*}{ Bahan } & \multicolumn{4}{c}{ Perbandingan pati garut dan tepung jewawut } \\
\cline { 2 - 5 } & $\mathbf{1 0 0 : 0}$ & $\mathbf{7 5 : 2 5}$ & $\mathbf{5 0 : 5 0}$ & $\mathbf{2 5 : 7 5}$ \\
\hline Telur ayam (gr) & 240 & 240 & 240 & 240 \\
Gula pasir (gr) & 200 & 200 & 200 & 200 \\
Pati Garut (gr) & $\mathbf{2 0 0}$ & $\mathbf{1 5 0}$ & $\mathbf{1 0 0}$ & $\mathbf{5 0}$ \\
Tepung Jewawut (gr) & - & $\mathbf{5 0}$ & $\mathbf{1 0 0}$ & $\mathbf{1 5 0}$ \\
Coklat Bubuk (gr) & 40 & 40 & 40 & 40 \\
Coklat Batang (gr) & 75 & 75 & 75 & 75 \\
Margarin (gr) & 80 & 80 & 80 & 80 \\
SP (gr) & 4 & 4 & 4 & 4 \\
Vanila bubuk (gr) & 10 & 10 & 10 & 10 \\
\hline
\end{tabular}

Tabel 2. Analisa karakteristik fisik dan kimia brownis kukus

\begin{tabular}{ll}
\hline \multicolumn{1}{c}{ Analisa } & \multicolumn{1}{c}{ Metode } \\
\hline $\begin{array}{l}\text { Fisik } \\
\text { Tekstur (kekerasan) }\end{array}$ & $\begin{array}{l}\text { Llyod (Bourne, 1982) } \\
\text { Wunter (Muhammad et al., 2018) } \\
\text { Kimia }\end{array}$ \\
Kadar air & Thermogravimetri (AOAC, 2016) \\
Kadar abu & Thermovolumetri (AOAC, 2016) \\
Kadar lemak & Ekstraksi Soxhlet (AOAC, 2016) \\
Kadar protein & Mikro-Kjeldhal (AOAC, 2016) \\
Kadar karbohidrat & By difference (Winarno, 2002) \\
Serat pangan & Enzimatis (AOAC, 2016) \\
\hline
\end{tabular}

Margarin dan coklat batang dicairkan dengan cara pengukusan. Telur, gula, dan SP diaduk rata dengan mixer sampai mengental. Kemudian ditambahkan campuran tepung dan coklat bubuk lalu diaduk hingga merata. Pada proses selanjutnya, margarin dan coklat batang yang telah dicairkan dimasukkan ke dalam adonan dan diaduk hingga merata. Vanili bubuk kemudian ditambahkan ke dalam adonan sebagai penambah citarasa. Adonan yang sudah jadi dituangkan ke dalam loyang kemudian dikukus selama 50 menit dengan api kecil. Brownis kukus selanjutnya dianalisa secara organoleptic serta fisik dan kimia seperti yang terlihat pada Tabel 2.

Analisa organoleptik yang dilakukan merupakan uji hedonic untuk mengetahui tingkat kesukaan panelis terhadap sampel produk brownis kukus. Uji hedonik dilakukan oleh 30 orang panelis tidak terlatih. Kepada panelis disajikan sampel dengan tiga komposisi pati garut dan tepung jewawut yang berbeda $(\mathrm{F} 1=75 \%$ pati garut : $25 \%$ tepung jewawut; $\mathrm{F} 2=50 \%$ pati garut : $50 \%$ tepung jewawut; $\mathrm{F} 3=25 \%$ pati garut : $75 \%$ tepung jewawut). Kemudian panelis diminta untuk memberikan penilaiannya terhadap sampel yang disajikan satu per satu tanpa membandingkan antar sampel dengan mengisi kuisioner berdasarkan tingkat kesukaan sesuai dengan skala penilaian yang telah ditentukan $(1=$ sangat tidak suka; $2=$ tidak suka; $3=$ netral; $4=$ suka; 5= sangat suka).

Dalam pengujian fisik, analisa tingat kekerasan dilakukan dengan Lloyd Universal Testing Machine. Sampel brownies diletakkan di atas plate. Alat diatur dengan kondisi dengan pre-load $0,02 \mathrm{~N}$, pre-load speed $50 \mathrm{~mm} / \mathrm{min}$ dan test speed $10 \mathrm{~mm} / \mathrm{min}$. Data yang diperoleh berupa kurva hubungan antara Stress (N) dan Crush (\%) serta Fmax (N). Nilai Fmax (N) digunakan untuk menyatakan tingkat kekerasan brownis. Analisa warna dilakukan dengan Chromamater Konica Minolta CR-4000. Dari analisa, didapatkan nilai $\mathrm{L}^{*}, \mathrm{a}^{*}$ dan $\mathrm{b}^{*}$ yang selanjutnya dapat digunakan untuk menghitung nilai ${ }^{\circ}$ Hue dengan rumus yang ditunjukan pada Eq. 1.

$$
{ }^{\circ} \text { Hue }=\tan ^{-1}\left(b^{*} / a^{*}\right) \quad \text { Eq. } 1
$$


Untuk menguji kadar air brownis kukus cokelat, sampel sebanyak 2-5 g dimasukan ke dalam cawan almunium yang telah diketahui bobotnya. Kemudian dikeringkan di dalam oven bersuhu 100105oC sampai bobot konstan. Setelah itu didinginkan di dalam desikator dan ditimbang. Kadar air sampel dihitung dengan rumus yang ditunjukan pada Eq. 2 .

$$
\begin{aligned}
& \text { Kadar air }(\%)= \\
& \frac{\text { bobot awal-bobot akhir }}{\text { bobot awal }} \times 100 \% \quad \text { Eq. } 2
\end{aligned}
$$

Untuk pengujian kadar abu brownis kukus cokelat, sampel sebanyak 3-5 g dimasukan ke dalam cawan porselin yang telah diketahui bobotnya, kemudian diabukan ke dalam furnace pada suhu $600^{\circ} \mathrm{C}$ selama kurang lebih 4 jam atau sampai diperoleh abu berwarna putih. Setelah itu cawan didinginkan dalam desikator sampai suhu ruang dan di timbang. Kadar abu sampel dihitung dengan rumus yang ditunjukan pada Eq. 3.

$$
\begin{aligned}
& \begin{array}{l}
\text { Kadar abu }(\%)= \\
\text { bobot abu (g) } \\
\text { bobot sampel (g) }
\end{array} \times 100 \%
\end{aligned}
$$

Untuk analisa kadar lemak brownis kukus cokelat, sebanyak 2-5 g sampel yang ditepungkan dibungkus dengan kertas saring, dimasukan ke dalam soxhlet, lalu ditambahkan heksan secukupnya dan direfluks selama 5-6 jam. Kemudian, labu lemak yang berisi lemak hasil ekstraksi dan pelarut dipanaskan pada oven dengan suhu 105oC setelah itu didinginkan dalam desikatot dan ditimbang. Kadar lemak sampel dihitung dengan rumus yang ditunjukan pada Eq. 4.

$$
\begin{aligned}
& \begin{array}{l}
\text { Kadar lemak }(\%)= \\
\text { bobot lemak (g) } \\
\text { bobot sampel (g) }
\end{array} \text { 100\% }
\end{aligned}
$$

Eq. 4

Sebanyak 0,1-0,5 g sampel dimasukkan ke dalam labu Kjeldahl $30 \mathrm{ml}$ dan ditambahkan 1,9 g K $\mathrm{SO}_{4} 40 \mathrm{mg} \mathrm{HgO}, 2 \mathrm{ml}$ $\mathrm{H}_{2} \mathrm{SO}_{4}$ dan beberapa butir batu didih. Kemudian, didihkan selama 60-90 menit sampai cairan jernih. Setelah itu didinginkan, ditambahkan sedikit $\mathrm{H}_{2} \mathrm{O}$ lewat dinding, dan didestilasi sampai diperoleh $15 \mathrm{ml}$ destilat berwarna hijau. Destilasi dilakukan dengan erlenmeyer $125 \mathrm{ml}$ berisi $5 \mathrm{ml} \mathrm{H}{ }_{3} \mathrm{BO}_{3} 2$ tetes indikator (campuran 2 bagian metal merah $0,2 \%$ dalam alkohol dan 1 bagian metilen blue $0,2 \%$ dalam alkohol), dan ditambahkan $8-10 \mathrm{ml} \mathrm{NaOH}-\mathrm{Na}_{2} \mathrm{~S}_{2} \mathrm{O}_{3}$. Hasil destilasi diencerkan sampai $50 \mathrm{ml}$ dan dititrasi dengan $\mathrm{HCl} 0,02 \mathrm{~N}$. Kadar protein dihitung dengan faktor konversi 6.25 dengan rumus yang ditunjukkan pada Eq. 5.

Kadar karbohidrat ditentukan dengan metode by difference yaitu dengan mengurangkan sampel dengn kadar air, kadar abu, kadar protein dan kadar lemak (Eq. 6).

$\operatorname{Kadar}$ protein $(\%)=\frac{\text { faktor konversi } \mathrm{x}(\mathrm{ml} \mathrm{HCl}-\mathrm{ml} \text { Blanko }) \times \mathrm{N} \mathrm{HCl} \times 14.0007 \times 100}{\mathrm{mg} \text { sampel }} \quad$ Eq. 5

Kadar karbohidrat (\%)

$=100 \%-(\%$ kadar air $+\%$ kadar abu $+\%$ kadar protein $+\%$ kadar lemak $)$ Eq. 6

Untuk menghitung kadar serat pangan, sampel (0.3-0.5 mm mesh) sebanyak 1 gram, dimasukkan dalam beaker $400 \mathrm{ml}$ lalu ditambahkan $50 \mathrm{ml}$ buffer posfat, $\mathrm{pH} 6,0$. Tambahkan $0.1 \mathrm{ml}$ Termamyl, tutup dengan aluminium foil dan masukkan ke dalam water bath mendidih selama 15 menit, digoyangkan setiap 5 menit. Selanjutnya, dinginkan sampel pada suhu kamar dan atur pH menjadi 7,5 0,2 dengan penambahan 10 ml larutan 0,275 $\mathrm{N} \mathrm{NaOH}$. Tambahkan $5 \mathrm{gr}$ protease dan $0,1 \mathrm{ml}$ larutan enzim $(50 \mathrm{mg}$ protease dalam $1 \mathrm{ml}$ buffer fosfat). Tutup dengan aluminium foil dan inkubasikan selama 30 menit. Dinginkan dan tambah 10

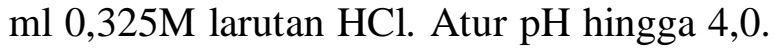
Tambahkan $0,3 \mathrm{~mL}$ amyloglukosidase, tutup dengan alumunium foil dan inkubasikan pada $60^{\circ} \mathrm{C}$ selama 30 menit dengan agitasi kontinyu. Tambahkan $280 \mathrm{ml}$ 95\% ETOH, panasi $60^{\circ} \mathrm{C}$ dan presipitasikan pada suhu kamar 60 menit. Saring dengan krus yg telah diberi celite $0,1 \mathrm{mg}$ yang diratakan dengan ETOH $78 \%$. Cuci residu dalam krus dengan 
$20 \mathrm{ml}$ ETOH $78 \%(3 \mathrm{x}), 10 \mathrm{ml}$ ETOH $95 \%$ (2x) dan $10 \mathrm{ml}$ aseton (1x). Keringkan residu dalam oven vakum $70^{\circ} \mathrm{C}$ semalam atau oven $105^{\circ} \mathrm{C}$ sampai berat konstan. Kadar serat pangan dihitung dengan Eq. 7 dengan a adalah berat sampel konstan, $b=$ berat $a b u$, $\mathrm{w}=$ berat awal sampel.

\section{Serat pangan $(\%)=(a-b) / w \times 100 \%$} Eq. 7

Rancangan penelitian menggunakan pola rancangan acak lengkap (RAL) dengan satu variabel independen yaitu varasi subtitusi tepung jewawut. Data selanjutnya dianalisis secara statistik menggunakan metode one way Analysis of Variance (ANOVA), jika terdapat perbedaan maka dilanjutkan dengan uji beda nyata menggunakan Duncan's Multiple Range Test (DMRT) pada taraf signifikansi $\alpha=5 \%$. Karakteristik fisik dan gizi formulasi terpilih dibandingkan dengan kontrol (100\% pati garut) menggunakan analisis metode independent $T$-test pada taraf signifikansi $\alpha=$ $5 \%$.

\section{HASIL DAN PEMBAHASAN}

Tingkat kesukaan panelis terhadap brownis kukus cokelat berbahan pati garut dengan subtitusi parsial tepung jewawut
Tabel 3 menunjukkan bahwa variasi formulasi tidak berpengaruh nyata $(\alpha=0,05)$ terhadap kesukaan panelis terhadap parameter warna brownis kukus cokelat, dengan nilai berkisar pada 3,50-3,90 (netral hingga suka). Hal ini disebabkan ketiga sampel variasi formulasi brownies kukus menghasilkan warna yang hampir sama yaitu coklat kehitaman yang dihasilkan dari bahan cokelat batang dan coklat bubuk yang digunakan. Faktor subtitusi pati garut menggunakan tepung jewawut tidak merubah warna secara signifikan (Gambar 1), sehingga tidak berdampak pada penilaian konsumen terhadap produk tersebut. Fenomena yang sama terjadi pada parameter aroma.Variasi formulasi tidak memberikan pengaruh nyata $(\alpha=0,05)$ terhadap parameter aroma brownis kukus cokelat. Penilaian yang diberikan panelis terhadap tiga sampel berkisar 3,47-3,63 yang berarti penilaian panelis terhadap parameter aroma brownies antara netral hingga suka. Menurut Fathullah (2013) aroma brownis adalah harum khas cokelat. Sifat bahan baku tepung jewawut yang dikenal memiliki bau agak apek ternyata tidak mempengaruhi kesukaan panelis terhadap aroma yang dihasilkan brownis kukus cokelat. Penambahan vanila bubuk dalam formulasi mungkin dapat berkontribusi untuk mengurangi bau apek dari tepung jewawut.

Tabel 3 Tingkat penerimaan panelis terhadap brownis kukus cokelat berbahan dasar pati garut dan tepung jewawut

\begin{tabular}{|c|c|c|c|c|c|}
\hline $\begin{array}{c}\text { Pati Garut: } \\
\text { Tepung Jewawut }\end{array}$ & Warna & Aroma & Rasa & Tekstur & Overall \\
\hline $75: 25$ & $3,50^{\mathrm{a}}$ & $3,63^{\mathrm{a}}$ & $3,27^{\mathrm{a}}$ & $2,83^{\mathrm{a}}$ & $3,27^{\mathrm{a}}$ \\
\hline $50: 50$ & $3,90^{\mathrm{a}}$ & $3,57^{\mathrm{a}}$ & $3,90^{\mathrm{b}}$ & $3,60^{6}$ & $3,93^{b}$ \\
\hline $25: 75$ & $3,67^{\mathrm{a}}$ & $3,47^{\mathrm{a}}$ & $3,43^{\mathrm{ab}}$ & $3,07^{\mathrm{a}}$ & $3,43^{b}$ \\
\hline
\end{tabular}

*) Notasi yang sama pada kolom yang sama menunjukkan tidak beda nyata pada $\alpha=0,05$

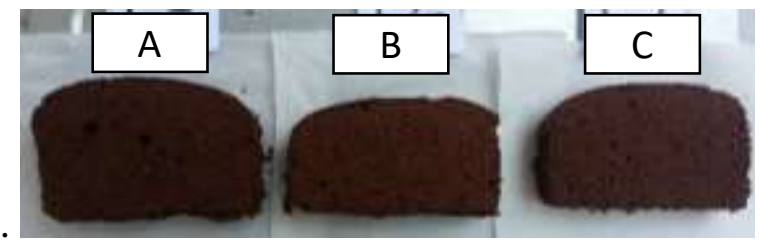

Gambar 1 Kenampakan brownis kukus cokelat berbahan pati garut dengan subtitusi tepung jewawut pada berbagai rasio $(A=75: 25 ; B=50: 50 ; C=25: 75)$ 
Pada parameter tekstur, tingkat kesukaan panelis terhadap brownis kukus cokelat dengan formulasi $50 \%$ pati garut dan $50 \%$ tepung jewawut berbeda nyata $(\alpha=0,05)$ dengan sampel tingkat kesukaan panelis pada brownies kukus dengan formulasi $75 \%$ pati garut dan $25 \%$ tepung jewawut serta $25 \%$ pati garut dan $75 \%$ tepung jewawut. Brownis cokelatkukus dengan formulasi $50 \%$ pati garut dan $50 \%$ tepung jewawut paling disukai panelis dengan rata-rata nilai kesukaan sebesar 3,60. Tepung jewawut memiliki tekstur yang agak kasar karena kandungan seratnya. Semakin banyak perbandingan subtitusi tepung jewawut maka tingkat keremahan semakin tinggi sehingga menghasilkan tekstur brownies kukus yang rapuh. Sedangkan subtitusi pati garut menghasilkan tekstur brownies kukus yang lebih padat dan sedikit keras. Kandungan gluten yang tidak dimiliki pati garut menjadi salah satu faktor yang menyebabkan tekstur brownies lebih padat dan sedikit keras. Penggunaan tepung tanpa gluten menyebabkan kekerasan meningkat sebagai akibat pengembangan yang kurang baik atau penurunan volume roti. Pada penelitian ini brownies kukus yang paling disukai panelis adalah dengan formulasi $50 \%$ pati garut dan $50 \%$ tepung jewawut, yaitu formulasi yang menghasilkan tekstur yang tidak terlalu padat dan tidak terlalu rapuh. Maka dapat diketahui bahwa tingkat kesukaan panelis terhadap tekstur brownies kukus pati garut dan tepung jewawut dipengaruhi oleh tingkat kepadatan dan kerapuhan. Panelis cenderung menyukai tekstur brownies kukus yang tidak terlalu padat tetapi tidak terlalu rapuh.

Pada parameter rasa, penilaian yang diberikan panelis terhadap tiga sampel berkisar 3,27-3,90 yang berarti antara netral hingga suka. Tingkat kesukaan panelis terhadap sampel brownis kukus cokelat dengan formulasi $50 \%$ pati garut dan $50 \%$ tepung jewawut berbeda nyata $(\alpha=0,05)$ dengan sampel brownies kukus $75 \%$ pati garut dan $25 \%$ tepung jewawut. Sedangkan pada brownis kukus cokelat yang terbuat dari $25 \%$ pati garut dan $75 \%$ tepung jewawut, mempunyai tingkat kesukaan panelis yang tidak berbeda nyata $(\alpha=0,05)$ terhadap kedua sampel lainnya. Berdasarkan evaluasi nilai kesukaan panelis dapat diketahui bahwa brownis kukus cokelat dengan formulasi $50 \%$ pati garut dan $50 \%$ tepung memiliki nilai kesukaan paling tinggi yaitu sebesar 3,90. Rasa brownis kukus cokelat juga dipengaruhi oleh jumlah penggunaan gula, coklat masak dan coklat bubuk yang menjadikan brownies memiliki rasa manis legit khas coklat. Rasa brownies merupakan kombinasi mutlak antara dua unsur rasa manis dan coklat (Fathullah, 2013). Ketiga variasi formulasi brownies kukus menghasilkan rasa dominan manis khas coklat.

Secara keseluruhan (overall) nilai ratarata kesukaan panelis pada brownies kukus pati garut dan tepung jewawut berkisar antara 3,27-3,93 yaitu pada kategori antara netral hingga suka. Selain pada parameter kesukaan, parameter warna, aroma, tekstur dan rasa produk brownies kukus dengan formulasi $50 \%$ pati garut dan $50 \%$ tepung jewawut memiliki tingkat penerimaan panelis tertinggi. Maka pada penelitian ini brownis kukus cokelat dengan formulasi 50\% pati garut dan $50 \%$ tepung jewawut merupakan formulasi terpilih berdasarkan penerimaan panelis. Penelitian sebelumnya dalam Damat dan Pangestuti (2006) juga menunjukkan bahwa perlakuan subtitusi tepung terigu dengan pati garut sebesar 50\% merupakan hasil yang terbaik dalam pembuatan roti cake.

Hasil yang diperoleh di dalam penelitian ini mengkonfirmasi bahwa reformulasi brownis dapat merubah tingkat penerimaan panelis terhadap produk tersebut. Uruakpa dan Fleischer (2016) menyatakan bahwa penggunaan kacang hitam (black bean) sebanyak 20-90\% dapat menurunkan secara signifikan tingkat penerimaan panelis terhadap produk brownis. Selaras dengan hasil penelitian tersebut, Yeom et al (2016) menjelaskan bahwa pencampuran bekatul dapat meningkatkan kadar serat pangan brownis, namun berdampak pada penurunan tingkat penerimaan panelis. Menariknya, Selvakumaran et al., (2019) yang melakukan subtitusi brownis tepung terigu dengan menggunakan tepung ubi jalar menemukan bahwa ubi jalar justru dapat meningkatkan tingkat penerimaan panelis terhadap produk brownis. Namun penelitian lebih lanjut oleh 
Ligarnasari et al (2018) menemukan bahwa penambahan minyak jintan hitam pada brownis berbahan ubi jalar menurunkan secara drastic tingkat kesukaan konsumen. Pada penelitian lainnya, English et al (2019) menyebutkan bahwa brownies yang dibuat dengan bahan dasar kacang buncis (Phaseolus vulgaris) dengan berbagai variasi perlakuan mempunyai tingkat penerimaan panelis yang tinggi dengan rerata 7 dari nilai maksimal 9.

\section{Karakteristik fisik brownis kukus cokelat formula terpilih}

Pengujian warna dan tekstur dilakukan untuk mengetahui pengaruh dari subtitusi parsial tepung jewawut terhadap pati garut pada produk brownis kukus cokelat (Tabel 4). Subtitusi tepung jewawut terhadap pati garut tidak menghasilkan perbedaan nyata $(\alpha=0,05)$ pada parameter $L^{*}$ (Lightness), $a^{*}$ dan $b^{*}$. Demikian pula pada nilai ${ }^{\circ}$ Hue yang diperoleh dari persamaan ${ }^{\circ} \mathrm{Hue}=\operatorname{arc} \tan$ $\left(b^{*} / a^{*}\right)$. Nilai L merupakan derajat kecerahan bahan, nilai $\mathrm{a}^{*}$ menyatakan cahaya pantul yang menghasilkan warna kromatik campuran merah-hijau, sedangkan nilai $\mathrm{b}^{*}$ menyatakan warna kromatik campuran birukuning (Muhammad et al., 2018). Nilai ${ }^{\circ} \mathrm{Hue}$ mencerminakan daerah kisaran warna kromatisitas yang berbeda. Nilai ${ }^{\circ}$ Hue pada brownis kukus cokelat adalah pada kisaran 39,7 hingga 40,3 sehingga menunjukkan bahwa produk tersebut berada pada daerah kisaran warna merah. Warna brownies kukus cenderung coklat kehitaman. Nilai $L^{*}, a^{*}, b^{*}$ selanjutnya dapat digunakan untuk menghitung derajat perbedaan warna $(\Delta \mathrm{E})$ untuk mengetahui tingkat perbedaan warna antar kedua sampel. Dari hasil perhitungan didapatkan nilai $\Delta \mathrm{E}$ sebesar 0,74 . Hal ini menunjukkan tingkat perbedaan warna kedua sampel tersebut sangat kecil untuk dapat dideteksi oleh indera mata. Hal ini merupakan salah satu alasan kenapa tingkat kesukaan panelis terhadap brownis kukus cokelat pada parameter warna tidak berbeda nyata.

Selain secara sensoris, parameter tekstur brownis kukus cokelat juga diukur secara objektif untuk mengetahui perbedaan tingkat kekerasan kedua sampel. Pengukuran tekstur dilakukan secara objektif untuk mengukur gaya yang diperlukan untuk menekan atau memberi beban produk sehingga produk mengalami deformasi. Hasil pengujian menunjukkan terdapat perbedaan nyata $(\alpha=0,05)$ terhadap tekstur pada brownis kukus cokelat kontrol $(100 \%$ pati garut kontrol) dengan brownis kukus cokelat yang diformulasikan dari $50 \%$ pati garut dan $50 \%$ tepung jewawut di mana brownis kukus cokelat kontrol memiliki tekstur yang lebih keras. Hal ini sesuai dengan hasil uji sensoris terhadap parameter tekstur, dimana brownies kukus yang diformulasikan dengan subtitusi parsial tepung jewawut sebanyak 50\% merupakan formulasi yang seimbang dengan menghasilkan tekstur yang tidak terlalu padat tetapi tidak terlalu rapuh. Sifat tepung jewawut yang sedikit kasar karena kandungan seratnya membuat tekstur produk memiliki tingkat keremahan yang tinggi sehingga jika komposisi yang ditambahkan terlalu banyak akan dihasilkan tekstur produk yang rapuh.

Tabel 4 Karakteristik warna dan tekstur brownis kukus cokelat berbahan dasar pati garut dengan subtitusi parsial tepung jewawut

\begin{tabular}{ccc}
\hline \multicolumn{1}{c}{ Parameter } & $\begin{array}{c}\text { Kontrol } \\
(\mathbf{1 0 0 \%} \text { pati garut) }\end{array}$ & $\begin{array}{c}\text { Pati garut : tepung jewawut } \\
\mathbf{5 0 0 5 0}\end{array}$ \\
\hline Warna & & \\
$\mathrm{L}^{*}$ & $31,4^{\mathrm{a}} \pm 0,5$ & $31,5^{\mathrm{a}} \pm 0,7$ \\
$\mathrm{a}^{*}$ & $6,8^{\mathrm{a}} \pm 0,2$ & $7,3^{\mathrm{a}} \pm 0,5$ \\
$\mathrm{~b}^{*}$ & $5,7^{\mathrm{a}} \pm 0,3$ & $6,2^{\mathrm{a}} \pm 0,6$ \\
。 Hue & $39,7^{\mathrm{a}} \pm 0,9$ & $40,3^{\mathrm{a}} \pm 1,2$
\end{tabular}

Tekstur

$\operatorname{Fmax}(\mathrm{N}) \quad 0,92^{\mathrm{a}} \pm 0,10 \quad 0,8^{\mathrm{b}} \pm 0,1$

*) Notasi yang sama pada baris yang sama menunjukkan tidak beda nyata pada $\alpha=0,05$ 
Warna dan tekstur brownis sangat dipengaruhi oleh formulasi produk. Penurunan nilai $\mathrm{L}^{*}, \mathrm{a}^{*}$ dan $\mathrm{b}^{*}$ brownis yang diakibatkan dari subtitusi tepung terigu dengan tepung ubi jalar telah dilaporkan oleh Selvakumaran et al. (2019). Subtitusi tersebut juga dilaporkan dapat menyebabkan produk brownis semakin keras (semakin tinggi proporsi ubi jalar, semakin keras brownis yang dihasilkan). Dalam penelitian Ligarnasari et al. (2018), penambahan $0.25 \%$ minyak jintan hitam dapat secara signifikan menurunkan tingkat kekerasan brownies dari $9.9 \mathrm{~N}$ menjadi $7.0 \mathrm{~N}$. Menariknya, menurut Richardson et al. (2018), sifat fisik brownis (kekerasan dan warna) tidak hanya dipengaruhi oleh formula brownis, namun juga dipengaruhi oleh ukuran partikel gula yang digunakan untuk membuat brownis. Semakin kecil ukuran gula yang digunakan, brownis yang dihasilkan cenderung lebih lunak dan lebih terang.

\section{Karakteristik kimia dan gizi brownis kukus cokelat formula terpilih}

Tabel 5 menunjukkan karakteristik kimia brownis kukus cokelat berbahan dasar pati garut dengan subtitusi parsial tepung jewawut. Subtitusi tepung jewawut terhadap pati garut tidak menghasilkan perbedaan nyata $(\alpha=0,05)$ pada parameter kadar air. Kadar air brownis kukus cokelat berkisar pada $36 \%$ hingga $40 \%$. Bahan yang dikukus dalam waktu yang lebih lama akan memberi kesempatan kepada bahan tersebut untuk menyerap uap air lebih besar sehingga mengakibatkan peningkatan kadar air bahan. Kadar air menjadi karakteristik suatu bahan pangan yang sangat penting karena kaitannya erat dengan umur simpan. Selain itu, kadar air juga dapat mempengaruhi kenampakan, tekstur serta cita rasa pada bahan pangan tersebut. Sampai saat ini, standar mutu borwnies yang diatur dalam Standar Nasional Indonesia (SNI) belum ada, sehingga kadar air roti yang diatur dalam SNI 01-3840-1995 seringkali digunakan sebagai pembanding. Menurut SNI 01-3840-1995 kadar air roti maksimal adalah sebesar $40 \%$. Dengan demikian, kadar air kedua brownies kukus yang dihasilkan telah memenuhi persyaratan standar mutu. Selain pada kadar air, subtitusi tepung jewawut terhadap pati garut tidak menghasilkan perbedaan nyata $(\alpha=0,05)$ pada kadar kadar abu. Nilai kadar abu produk pangan mencerminkan besarnya kandungan mineral bahan di dalam produk tersebut. Menurut Sudarmadji (2003) mineral yang terdapat dalam suatu bahan dapat merupakan dua macam garam yaitu garam organik (asam malat, oksalat, asetat dan pektat) dan garam anorganik (fosfat, karbonat, klorida, sulfat dan nitrat).

Subtitusi tepung jewawut terhadap pati garut menghasilkan perbedaan nyata $(\alpha=0,05)$ pada kadar lemak, protein, karbohidrat dan serat pangan. Perbedaan tersebut disebabkan oleh perbedaan komposisi pati garut dan tepung jewawut. Menurut Slamet et al. (2019), pati garut mempunyai kadar protein $0,45 \%$, kadar lemak $0,35 \%$, karbohidrat $81,8 \%$ dan serat pangan $2,16 \%$. Sedangkan tepung jewawut mempunyai kadar protein $11,8 \%$, kadar lemak $6,4 \%$, karbohidrat $72,2 \%$ dan serat pangan $\quad 7,8 \%$ (Dias-Martins, 2018).

Tabel 5 Karakteristik kimia brownis kukus cokelat berbahan dasar pati garut dengan subtitusi parsial tepung jewawut

\begin{tabular}{lcc}
\hline \multirow{2}{*}{ Komponen Gizi } & \multicolumn{2}{c}{ Pati Garut : Tepung Jeawawut } \\
\cline { 2 - 3 } & $100: 0$ & $50: 50$ \\
\hline Air $(\% \mathrm{db})$ & $36,00^{\mathrm{a}}$ & $39,40^{\mathrm{a}}$ \\
Abu $(\% \mathrm{db})$ & $1,75^{\mathrm{a}}$ & $1,79^{\mathrm{a}}$ \\
Lemak $(\% \mathrm{db})$ & $20,35^{\mathrm{a}}$ & $21,60^{\mathrm{b}}$ \\
Protein $(\% \mathrm{db})$ & $8,69^{\mathrm{a}}$ & $10,01^{\mathrm{b}}$ \\
Karbohidrat $(\% \mathrm{db})$ & $77,13^{\mathrm{a}}$ & $76,99^{\mathrm{b}}$ \\
Serat Pangan $(\% \mathrm{db})$ & $2,32^{\mathrm{a}}$ & $3,07^{\mathrm{b}}$ \\
\hline *) Notasi yang sama pada baris yang sama menunjukkan tidak beda nyata pada $\alpha=0,05$
\end{tabular}


Subtitusi parsial tepung jewawut pada pati garut untuk pembuatan brownis kukus cokelat dapat meningkatkan kadar protein, kadar lemak dan serat pangan. Peningkatan serat pangan tersebut membuka peluang untuk membuat produk brownis kukus cokelat yang lebih sehat. Serat pangan atau dietary fiber merupakan bagian dari tumbuhan yang dapat dikonsumsi dan tersusun dari karbohidrat yang memiliki sifat resistan terhadap proses pencernaan dan penyerapan di usus halus manusia serta mengalami fermentasi sebagian atau keseluruhan di usus besar. Serat pangan umumnya termasuk kelompok karbohidrat yang tidak dapat dicerna dan diserap oleh sistem pencernaan manusia normal. Manfaat serat pangan bagi kesehatan yaitu mencegah terjadinya sembelit, memperlancar buang air besar, mengurangi resiko penyakit jantung dan menurunkan kolesterol dalam darah (Fuller et al., 2016).

Perubahan karaktersitik kimia brownis akibat dari reformulasi produk juga telah dipublikasikan pada penelitian-penelitian terdahulu. Uruakpa dan Fleischer (2016) menyebutkan bahwa penggunaan kacang hitam dapat meningkatkan kadar protein, vitamin A, zat besi, kalsium dan serat pangan, dan pada saat yang sama menurunkan kadar lemak serta total kalori dari brownies. Ligarnasari et al. (2018) menyatakan bahwa penambahan minyak jintan hitam dapat secara signifikan menaikkan kadar lemak (asam palmitat, asam oleat dan asam laurat), kadar protein, kadar abu dan total fenol serta menigkatkan aktifitas brownis berbahan dasar ubi jalar. Pada penelitian Yeom et al (2016), penambahan bekatul dapat meningkatkan kadar serat pangan brownis, namun hal ini dapat berdampak pada penurunan tingkat penerimaan panelis

\section{Angka kecukupan gizi dan serat pangan brownis kukus cokelat formula terpilih}

Energi brownis cekelat kukus diperoleh dengan mengkonversikan karbohidrat, lemak dan protein, dimana dihasilkan 9 kkal per gram untuk lemak serta 4 kkal per gram untuk karbohidrat dan protein. Hasil perhitungan kalori brownies kukus cokelat diperoleh 365 kkal per 100 gram takaran saji.
Namun brownis kukus cokelat sampai saat ini masih termasuk makanan selingan yang memberikan kontribusi sebesar $10 \%$ dari total kebutuhan energi per hari. Angka label gizi untuk energi bagi golongan umum adalah 2000 kkal. Setiap 100 gram brownies kukus pati garut dan tepung jewawut dari formula terbaik mengandung $365 \mathrm{kkal}$. Sehingga untuk memperoleh 200 kkal dibutuhkan 54 gram brownies kukus pati garut dan tepung jewawut. Komposisi kandungan zat gizi brownis kukus cokelat pati garut dan tepung jewawut per takaran saji dapat dilihat pada Tabel 6.

Tabel 6 Kandungan gizi brownies kukus terbaik per takaran saji (54 gram)

\begin{tabular}{lcc}
\hline Kandungan Gizi & $\begin{array}{c}\text { Jumlah } \\
\text { asupan }\end{array}$ & $\begin{array}{c}\text { Anjuran } \\
\text { asupan }\end{array}$ \\
\hline Protein (gr) & 3,85 & $5-7,5$ \\
Lemak (gr) & 8,37 & 5,56 \\
Karbohidrat (gr) & 26,62 & 27,5 \\
Serat Pangan (gr) & 1,18 & 25 \\
Energi (kkal) & \multicolumn{2}{c}{200} \\
\hline
\end{tabular}

Dalam Widyakarya Nasional Pangan dan Gizi XI Tahun 2018, asupan protein yang dianjurkan yaitu $10-15 \%$ dari total kalori. Sehingga didapatkan asupan protein 5-7,5 gram per satu takaran saji. Dalam satu takaran saji brownies kukus mengandung protein sebanyak 3,85 gram, sehingga kandungan protein dalam produk brownies kukus ini belum dapat mendekati anjuran asupan protein. Kebutuhan protein juga akan didapatkan dari makanan selingan lainnya. Asupan lemak yang dianjurkan yaitu tidak melebihi $25 \%$ dari total kalori. Maka didapatkan asupan lemak tidak melebihi 5,56 gram per takaran saji. Sedangkan dalam satu takaran saji brownies kukus mengandung lemak sebanyak 8,37 gram, sehingga dapat diketahui bahwa kadar lemak produk brownies kukus melebihi anjuran asupan lemak yang dianjurkan. Tingginya kadar lemak dapat disebabkan oleh bahan-bahan yang ditambahkan dalam pembuatan brownies sebagai sumber lemak. Pengurangan komposisi bahan-bahan sumber lemak seperti margarin, coklat masak dan coklat bubuk dalam komposisi brownies dapat menurunkan kadar lemak produk sehingga dapat sesuai dengan asupan yang dianjurkan. Asupan karbohidrat yang 
dianjurkan yaitu 50-65\% dari total kalori. Sehingga didapatkan asupan karbohidrat yang dianjurkan sebanyak 25-32,5 gram per satu takaran saji. Dalam satu takaran saji brownies kukus mengandung karbohidrat sebanyak 26,62 gram, maka kandungan karbohidrat dalam produk brownies kukus ini dapat dikatakan telah sesuai anjuran asupan karbohidrat.

Selain protein, lemak dan karbohidrat, serat pangan merupakan komponen dalam bahan pangan yang data ini mendapatkan perhatian, karena telah terbukti mempunyai dampak positif bai kesehatan. Namun hingga saat ini belum ada patokan baku atas konsumsi serat untuk setiap orang. Anjuran biasanya ditujukan untuk kelompok tertentu. US FDA menganjurkan total dietary fiber (TDF) 25 gram/2000 kalori atau 30 gram/2500 kalori. The American Cancer Society, The American Heart Association dan The American Diabetic Association menyarankan 25-35 gram/hari dari berbagai bahan makanan. Konsensus nasional pengelolaan diabetes di Indonesia menyarankan 25 gram/hari bagi orang yang berisiko menderita DM.

Jumlah serat pangan total per takaran saji brownis kukus cokelat yang diformulasikan dari pati garut dan tepung jewawut sebesar 1,18 gram. Kebutuhan serat pangan per hari untuk golongan umum menurut Angka Label Gizi untuk pelabelan adalah sebanyak 25 gram/2000 kkal. Dari perhitungan dapat diketahui bahwa brownies kukus pati garut dan tepung jewawut memberikan kontribusi sebesar $4,72 \%$ dari total kebutuhan sehari golongan umum. Dalam Widyakarya Nasional Pangan dan Gizi XI Tahun 2018, dinyatakan bahwa produk yang mengandung 10-20\% suatu zat gizi tertentu dari total kebutuhan sehari dikatakan sebagai produk sumber zat gizi tersebut. Sehingga brownies kukus dengan subtitusi $50 \%$ tepung jewawut belum dapat dikatakan sebagai pangan sumber serat. Menurut BPOM (2016) suatu produk dapat diklaim sebagai sumber serat pangan jika komposisi serat pangan tidak kurang dari 3 gram/100 gram produk. Sedangkan produk dapat diklaim sebagai tinggi serat pangan jika komposisi serat pangan tidak kurang dari
6 gram/100 gram produk. Berdasarkan hasil analisis serat pangan yang telah dilakukan dapat diketahui bahwa dengan kandungan serat pangan brownis kukus cokelat terpilih (50\% pati garut : $50 \%$ tepung jewawut) yaitu $2,18 \%$ (wb) dimana belum dapat memenuhi persyaratan pangan sumber serat maupun tinggi serat.

American Academy of Pediatrics juga menyarankan kebutuhan TDF sehari untuk anak adalah jumlah umur (tahun) ditambah dengan 5 gram. Pada Tabel 4.9 dapat dilihat kebutuhan serat pangan yang dapat dipenuhi untuk rentang usia anak-anak (5-12 tahun) dengan mengonsumsi satu takaran saji brownies kukus. Berdasarkan Tabel 7 dapat diketahui bahwa anak usia 5 tahun dapat memenuhi kebutuhan serat pangannya per hari sebesar $11,8 \%$ dengan mengonsumsi brownis kukus cokelat yang diformulasikan dari pati garut dan tepung jewawut per satu takaran saji. Anak usia 6 tahun dapat memenuhi $10,73 \%$ dari kebutuhan serat pangannya per hari. Anak usia 7, 8, 9, 10, 11 dan 12 tahun secara berturut-turut dapat memenuhi $9,83 \%, 9,08 \%, 8,43 \%, 7,87 \%$, $7,38 \%$ dan $6,94 \%$ dari kebutuhan serat pangannya per hari. Dari nilai \% AKG yang dipenuhi menunjukkan bahwa produk brownis kukus cokelat yang dibuat dari pati garut dan tepung jewawut dapat disebut sebagai produk pangan sumber serat untuk segmen anak usia 5 dan 6 tahun karena dapat memenuhi lebih dari 10\% kebutuhan serat pangan per hari. Sedangkan untuk anak usia 7-12 tahun nilai \%AKG yang dipenuhi produk brownis kukus cokelat yang dibuat dari pati garut dan tepung jewawut ini belum memenuhi persyaratan. Kontribusi terhadap asupan serat pangan dalam satu takaran saji produk untuk anak usia 7-12 tahun masih dibawah $10 \%$ sehingga brownies kukus pati garut dan tepung jewawut belum dapat menjadi produk pangan sumber serat.

Tabel 7 Kebutuhan serat pangan golongan usia anak

\begin{tabular}{ccc}
\hline $\begin{array}{c}\text { Usia } \\
\text { (tahun) }\end{array}$ & $\begin{array}{c}\text { Kebutuhan Serat } \\
\text { Pangan } \\
\text { (gram/hari) }\end{array}$ & $\%$ AKG \\
\hline 5 & 10 & 11,8 \\
6 & 11 & 10,73 \\
7 & 12 & 9,83 \\
\hline
\end{tabular}




\begin{tabular}{ccc}
\hline 8 & 13 & 9,08 \\
9 & 14 & 8,43 \\
10 & 15 & 7,87 \\
11 & 16 & 7,38 \\
12 & 17 & 6,94 \\
\hline
\end{tabular}

\section{KESIMPULAN}

Berdasarkan hasil penelitian yang telah dilakukan, formulasi yang mendapatkan penilaian tertinggi panelis yaitu brownis kukus cokelat yang diformulasi dengan 50\% pati garut dan $50 \%$ tepung jewawut. Brownis kukus cokelat ini mempunyai kadar air $28,2 \%$, kadar abu $1,8 \%$, kadar protein $8,7 \%$, kadar lemak 21,6\%, kadar karbohidrat $77,1 \%$, serta serat pangan $3,1 \%$. Dengan kadar serat tersebut, brownis kukus cokelat ini dapat disebut sebagai produk pangan sumber serat untuk anak umur 5-6 tahun karena dapat memberikan kontribusi diatas $10 \%$ dari total kebutuhan sehari serat pangan pada golongan anak pada usia tersebut. Subtitusi $50 \%$ tepung jewawut mempunyai perbedaan warna yang sangat kecil dibandingkan brownis kukus control, namun menyebabkan penurunan tingkat kekerasan. Untuk industrialisasi dan komersialisasi produk ini, penelitian dapat dilanjutkan dengan mengkaji umur simpan brownis kukus cokelat.

\section{DAFTAR PUSTAKA}

Arslan, M., Rakha, A., Xiaobo, Z., \& Mahmood, M. A. (2019). Complimenting gluten free bakery products with dietary fiber: Opportunities and constraints. Trends in food science \& technology, 83, 194-202.

AOAC. (2016). Official Methods of Analysis of the Association of Official Analytical Chemistry Intrnational $20^{\text {th }}$ Edition. Arlington: AOAC Inc

Bourne, M. C. (2002). Food Texture and Viscosity Concept and Measurement 2nd Edition. New York: Academic Press.

BPOM. (2016). Peraturan Kepala Badan Pengawas Obat dan Makanan Republik
Indonesia Nomor 13 Tahun 2016 Tentang Pengawasan Klaim Pada Label dan Iklan Pangan Olahan. Badan POM Republik Indonesia.

Brownlee, I. A., Chater, P. I., Pearson, J. P., \& Wilcox, M. D. (2017). Dietary fibre and weight loss: Where are we now? Food Hydrocolloids, 68, 186-191.

Dai, F. J., \& Chau, C. F. (2017). Classification and regulatory perspectives of dietary fiber. Journal of Food and Drug Analysis, 25(1), 37-42.

Damat dan Pangestuti, A.P. (2008). Subtitusi Tepung Terigu dengan Pati Garut (Maranta arundinacea L) pada Proses Pembuatan Cake. Prosiding Seminar Nasional Pangan 2016. Yogyakarta.

de Ridder, D., Kroese, F., Evers, C., Adriaanse, M., \& Gillebaart, M. (2017). Healthy diet: health impact, prevalence, correlates, and interventions. Psychology \& Health, 32: 907-941.

Dias-Martins, A. M., Pessanha, K. L. F., Pacheco, S., Rodrigues, J. A. S., \& Carvalho, C. W. P. (2018). Potential use of pearl millet (Pennisetum glaucum (L.) R. Br.) in Brazil: Food security, processing, health benefits and nutritional products. Food Research International, 109, 175-186.

English, M. M., Viana, L., \& McSweeney, M. B. (2019). Effects of soaking on the functional properties of yellow-eyed bean flour and the acceptability of chocolate brownies. Journal of Food Science, 84, 623-628.

Fathullah, Ali. (2013). Perbedaan Brownies Tepung Ganyong dengan Brownies Tepung Terigu Ditinjau dari Kualitas Inderawi dan Kandungan Gizi. Skripsi. Fakultas Teknik, Universitas Negeri Semarang. Semarang.

Fuller, S., Beck, E., Salman, H., \& Tapsell, L. (2016). New horizons for the study of dietary fiber and health: a review. Plant Foods for Human Nutrition, 71: 1-12. 
Hutchings, J. B. (1999). Food Colour and Appearance 2nd Edition. Maryand: Aspen Pub.

Ligarnasari, I. P., Anam, C., \& Sanjaya, A. P. (2018). Physical, chemical and sensory properties of brownies substituted with sweet potato flour (Ipomoea batatas L.) with addition of black cumin oil (Nigella sativa L.). In IOP Conference Series: Earth and Environmental Science (Vol. 102, No. 1, p. 012084). IOP Publishing.

Maphosa, Y., \& Jideani, V. A. (2016). Dietary fiber extraction for human nutrition-A review. Food Reviews International, 32(1), 98-115.

Muhammad, D. R. A., \& Dewettinck, K. (2017). Cinnamon and its derivatives as potential ingredient in functional fooda review. International Journal of Food Properties, 20: 2237-2263.

Muhammad, D. R. A., Saputro, A. D., Rottiers, H., Van de Walle, D., \& Dewettinck, K. (2018). Physicochemical properties and antioxidant activities of chocolates enriched with engineered cinnamon nanoparticles. European Food Research and Technology, 244, 1185-1202.

Richardson, A. M., Tyuftin, A. A., Kilcawley, K. N., Gallagher, E., O'Sullivan, M. G., \& Kerry, J. P. (2018). The impact of sugar particle size manipulation on the physical and sensory properties of chocolate brownies. $L W T, 95,51-57$.

Selvakumaran, L., Shukri, R., Ramli, N. S., Dek, M. S. P., \& Ibadullah, W. Z. W. (2019). Orange sweet potato (Ipomoea batatas) puree improved physicochemical properties and sensory acceptance of brownies. Journal of the Saudi Society of Agricultural Sciences, 18, 332-336.

Slamet, A., Praseptiangga, D., \& Hartanto, R. (2019). Physicochemical and Sensory Properties of Pumpkin (Cucurbita moschata D) and Arrowroot (Marantha arundinaceae L) Starch-based Instant
Porridge. International Journal on Advanced Science, Engineering and Information Technology, 9, 412-421.

Sudarmadji, S. (2003). Analisa Bahan Makanan dan Pertanian. Kanisius. Yogyakarta.

Uruakpa, F. O., \& Fleischer, A. M. (2016). Sensory and nutritional attributes of black bean brownies. American Journal of Food Science and Nutrition, 3, 27-36.

Winarno, F. G. (2002). Kimia Pangan dan Gizi. PT. Gramedia Pustaka Utama. Jakarta.

Yeom, K. H., Kim, J. H., Lee, J. H., Bae, I. H., \& Chun, S. S. (2016). Quality characteristics and consumer acceptability of brownies with rice bran dietary fiber. Journal of the Korean Society of Food Science and Nutrition, 45, 1823-1829. 